\title{
ELITE PROFILE AND TYPE OF INSTITUTIONAL TRANSFORMATION: COMPARISON OF RUSSIA AND SLOVENIA
}

Lea Prijon, Matevž Tomšič*

School of Advanced Social Studies in Nova Gorica, 5000 Nova Gorica, Slovenia

Abstract

Russia and Slovenia are in many aspects very dissimilar countries. The process of systemic change in the post-communist period was also usually assessed differently. Slovenia is an example of successful transformation that resulted in consolidated democracy and effective market economy, while Russia is an example of flawed democratisation, resulting in authoritarian reversal and an oligarchic economy with a combination of state interference and domination of 'olygarchs'. However, the global crisis revealed some severe structural weaknesses of the Slovenian model of transition that led to the development of a rather dysfunctional democracy and 'crony-capitalism' characterised by entanglement of political and business elite that is-at least in some aspects_-rather similar to the situation in Russia. We claim that these similarities between the two countries are predominantly determined by the type of elite formation and configuration, i.e. a high level of elite reproduction and ideological hegemony of one political faction that led to development of institutional setting with a number of 'extractive' characteristics.

Keywords

elites $\bullet$ institutions $\bullet$ post-communism $\bullet$ reproduction $\bullet$ Russia $\bullet$ Slovenia

\section{Introduction}

In the process of systemic transformation of former communist societies, the role of the elites, particularly political ones, is particularly important since it holds the responsibility for executing the so-called 'triple transition' (Offe 1993), meaning a change of political, economic, and social systems, the key to which is above all the re-establishment of structural conditions (system infrastructure, legislative framework) for the 'normal' functioning and autonomous development of other social areas (Adam 1994). We speak about elites as these individuals 'who are able, by the virtue of their strategic positions in powerful organisations, to affect national outcomes regularly and substantially' (Field et al. 1990, 152). Parliamentary democracy and market economy as the main institutional elements of modern society must be 'chosen, implemented and maintained by its "agents", i.e. political actors with their characteristic interests, passions, memories and virtues' (Schmitter 1993, 425). The course of societal transformation and the resulting institutional character of post-communist societies is thus strongly determined by the profile of elites and their strategic choices. It thus importantly affects their political and economic performance.
Russia and Slovenia are in many aspects very dissimilar countries. They essentially differ in terms of the size of their territory and number of inhabitants, since the former is one of the biggest countries in the world, while the latter is one of the smallest European Union (EU) members. They belong to different cultural traditions: the former is the one of the cradles of Orthodox Christianity ${ }^{1}$ while the latter historically belongs to the tradition of Western Christianity. They have different experience with statehood: the former as one of the world powers which played a significant role in European history, the latter as a country that only recently gained its independence. Although in the second half of twentieth century both countries experienced the same type of socioeconomic system, a number of their characteristics varied. The Slovenian regime was, in general, much more open, and Slovenia enjoyed more regional autonomy, while the

1 In his Clash of Civilizations and Remaking of World Order (1996), Samuel Huntington determined Russia as the centre of one the world' civilisations which is based on Eastern tradition of Christianity.

Corresponding author e-mail: matevz.tomsic@fuds.s

(C) 2021 Lea Prijon and Matevž Tomšič. This is an open access article distributed under the Creative Commons Attribution-NonCommercial-NoDerivs license (c)) BY

(http://creativecommons.org/licenses/by-nc-nd/4.0/) 
oppressiveness of the Soviet regime remained strong up until the beginning of perestroika. ${ }^{2}$ The process of systemic change in the post-communist period was thus usually assessed differently, with Slovenia being an example of successful transformation that resulted in consolidated democracy and effective market economy, and Russia being an example of flawed democratisation, resulting in authoritarian reversal and oligarchic economy with a combination of state interference and domination of 'oligarchs'.

However, the global crisis revealed some similarities. Slovenia has been affected by the crisis in a severe way. Due to its financial problems (high indebtedness, an 'immobilised' banking sector, and increasing budget deficit), this small EU country that used to be considered as a post-communist 'success story' came under the spotlight of institutions of the EU. The crisis uncovered structural weaknesses of Slovenian model of socio-economic regulation that led to development of its version of 'crony-capitalism' characterised by entanglement of political and business elite which is-at least in some aspects—rather similar to the situation in Russia.

This article deals with the question of how similar structural traits can appear in otherwise very dissimilar countries. We claim that is due in a predominant way to similar elite configurations. Namely, the above-mentioned common traits between the two countries are predominantly determined by the type of elite formation and configuration, i.e. a high level of elite reproduction of one political faction. This configuration is problematic, since it led to the development of an institutional setting with a number of 'extractive' characteristics (Acemoglu and Robinson 2012), hindering its developmental potential.

2. Post-communist Transformation as Modernisation

Modernisation is a very broad and complex concept, which was defined by Andorka as a combination of five processes: structural changes, improving the living standard; development of the welfare system; democratisation of the political system; and the creation of civil virtues, norms and values (Andorka 1993). As societies develop, social structures are becoming more complex politically, economically, and technologically developed, autonomous, and individualistic. With regard to these changes, Deutsch uses the term 'social mobilization' as a process where old economic and psychological features are substituted by new behavioural patterns and socialisation (for example, new technologies, urbanization, mass media, new norms, the availability of consumer goods, etc.) as well as structural views of social

2 Perestroika (the Russian word for 'reconstruction') was a reform movement within the Soviet party that was launched by its Secretary General, Mikhail Gorbachev (1985-1991). organisation (Deutsch in Rizman1989, 9). In addition, processes of modernisation include the implementation of new institutional patterns of economic development, modern political ideology, participation, etc.

Countries of the former Soviet Union, Eastern Europe, and other countries that were under communist rule functioned on the basis of state's supervision or rational redistribution (Konrad and Szenlenyi 1979). Such a system functioned on the basis of collective control of the communist nomenklatura over the 'means of production', with centralised steering of the economy and allocation of resources on the basis of planned strategies (Haraszti 1977). The regime's intervention in society's politics, economics and culture allowed a certain degree of modernisation, which can be called, due to the regime's rigidity and centralisation as 'inorganic modernisation directed from above' (Bozoki 1994, 68). Arnason (2000) defines modernisation processes in socialist and communist societies as 'alternative modernization' of communist society.

In the countries that practiced so-called 'real socialism', certain processes were unfolding that could be labelled modernisation, i.e. intensive industrialisation, urbanization, and establishment of a state with a strong bureaucratic apparatus. However, they were all strongly 'deformed' and differed considerably from those in developed Western societies (Adam 1989; Eisenstadt 1992). Industrialisation was based on the development of heavy industry and big, rigid, and inflexible complexes that were, due to the absence of private initiative, inefficient and uncompetitive. Urbanization was chaotic, as was manifested in the inorganic and inconsistent development of the cities and in an underdeveloped infrastructure. The bureaucratic apparatuses were established not to serve the needs of the citizenry so much as to exert control over them and curtail their liberties. ${ }^{3}$ Even the political system was characterised by some modern institutions like a constitution, elections, parliament, etc. that were, in the absence of political pluralism and due to the total domination of the Communist Party, only a façade of the undemocratic political building.

Post-communist modernisation, which tended towards a convergence of modern societies, can be divided into two parallel and interdependent processes. The first is the differentiation of social functional subsystems in relation to the political subsystem, where a self-restraint policy allows other social subsystems operating independently with their own rationales. The second process implies the development of opportunities for autonomous function

3 Communist regimes were characterised by severe and continuous violations of human rights and liberties, as manifested in the persecution of political and ideological dissent, confiscations of property, restricting the movement of the people, a ban on professional engagement of 'suspicious' individuals, etc (Kleindienst and Tomšič 2017; Avbelj and Letnar Černič 2020). 
of subsystems according to their own internal rationales, which entails the actual utilisation of these opportunities and development of their own self-referential logic. At the same time, the high degree of a subsystem's autonomy increases interdependence (Makarovič 1996, 126). Modernisation of post-communist societies is linked to the establishment of a modern institutional system with a democratic political regime and an efficient, market-oriented economic system (which is also a condition for EU admission).

Modernisation is successful when conditions are set for high-level performance in different societal fields as well as systemic competitiveness from a global perspective. This refers to establishment of 'inclusive' institutions both in the fields of politics and economy, which enables free engagements of individuals in groups in political process and business activities (Acemoglu and Robinson 2012). ${ }^{4}$ Such institutions are the basis for sustained societal development.

\section{Elites as Agents of Social Changes}

When we deal with the position and role of elites in their relationship to the social-historical context, the complexity of this mutual relationship needs to be emphasised. Both the character of the elites and their social position depend on cultural-historical circumstances, especially the relationship to the past institutional structure, and also the relationships with the other social groups (Eisenstaedt 1973, 34). The behaviour of political elites is deeply rooted in the political culture, which is a product of complex historical development. But this dependence of the elites on the existing social structures and predominant cultural forms is only present in a state of relative stability (Tomšič 2016).

In the context of the processes of social system change, it is plausible to define the political elite as 'those individuals and groups that create and control social institutions' (Kaminski and Kurczewska 1994, 136). This definition of the political elite does not only include members of the ruling structure, since a leading position in society (or an important segment of it) can in certain circumstances be occupied by groups that are not rooted in the ruling structure. But in the case of a successful overthrow, these usually also occupy the formal centres of power. It is worth noting that institutional changes can be initiated by actors from various social fields, not only from the sphere of politics. Actors from the field of culture, such as various artistic and intellectual groups, professional associations, and magazines can often find themselves in

4 Acemoglu and Robinson (2012) distinguish between two types of institutions: inclusive institutions, based on openness of engagement of different actors, and extractive institutions, based on exclusion and privileges of certain social groups. such a role after having become politically relevant through their public and general socially engaged activities. ${ }^{5}$ This is largely because in certain situations, their critique of the existing regime and their vision of social development can achieve mass support and thus decisively intervene in the process of political decision-making. Various non-political groups can also represent the origin of institutionalised political actors, mainly political parties that later act as agents of democratic change.

During times of intensive social change, the political elite or its dominant type is the one that has the biggest influence on the structure of and the way individual institutions operate, and thus also influences the nature of the newly formed social organisation (Tomšič 2016, 60). The configuration of elites, i.e. relationships between different factions of the political elite as well as between the political elite and other elite segments (business, cultural elite), and elite profile in terms of prevailing cultural patterns, exert strong impact on the course of societal development (Adam and Tomšič 2012, 54).

The character of the national elite is the factor that influences the developmental success-or failure-of the social system. Because it has a major influence, especially in turbulent times, on the nature of the regime and the shaping and functioning of key institutions, it is important to know its essential characteristics or which faction within it is the one that is most influential.

Social conditions in countries of the former communist bloc are largely characterised by the relationship between the so-called old and new elites, i.e. between the elite emerging from the ranks of the former regime and the relatively heterogeneous elite formed during the social transition (Adam and Tomšič 2002). It must, however, be stressed that it is often difficult to make a clear-cut division between the old and new elites. Even the former nomenklatura has in fact experienced various transformations, and part of it-at least the part that retained its position on the political scene-has embraced (at least formally) democratic principles and norms. Thus, the thought and action patterns that are essentially a relic of the former undemocratic system are often present in recently founded political parties.

Nevertheless, one of the key questions of post-socialist transformations concerns the position and role of former holders of monopolistic social power, i.e. the members of former communist elites: in other words, whether and to what extent they were able to retain key social resources and thereby continue to influence the development of these societies (Tomšič 2016).

5 One might mention the example of the Slovenian literary magain Nova revija, which become in 1980s one of the main generators of anti-regime ideas and programs, and its contributors became leading figures of the newly formed political oppostion. 
4. Elites and Societal Dynamics in Russia and Slovenia

Given that the conditions for extensive institutional structure change occurred after the breakup of communist regimes, it is important to know the nature of those groups that played the key role in shaping and carrying out these changes. When dealing with elites in post-communist countries, we naturally cannot avoid the historical context in which they developed (Tomšič 2016). The relationships between the individual categories within the elite are largely dependent on it, especially the question of which faction controls the key positions in society.

Elites, especially political ones, were at the beginning and during the transition process confronted with many dilemmas and challenges concerning the speed and scope of reforms and building of new institutions and regulations. The responses were determined by available resources, knowledge, and the interests of influential groups. In this context, the visions of the elite, its values and ideological profile also played a significant role in searching for the most appropriate developmental model (Adam, Kristan, and Tomšič. 2009).

\section{Elite Formation and Dynamics of Political Space}

Both Russia and Slovenia were formed by the dissolution of two multinational states-the Soviet Union and Yugoslavia (Russia was a dominant part of the former, while Slovenia was a minor part of the latter, struggling for equal status). In the former, democratisation started as transformation 'from above' i.e. within the regime structures (perestroika) while in the latter, it was a settlement between the reform faction of the Communist Party and rising anti-communist opposition.

\section{Russia}

Russia's transitional politics has strong personal traits. Political power is concentrated in the hands of the president, meaning it he personally determines political dynamics. This was the case with first Russian president, Boris Jeltsin, and it is even more evident with the current one, Vladimir Putin. This 'personification' is reflected in underdevelopment of political parties (Golosov 2003; 2006), whose activities have very limited effect on policy outcomes (Chaisty 2005).

Although the party system has somehow stabilised since the 1990s, its structure-in terms of its cleavages-still considerably differs not only from established Western democracies but also from the 'new democracies' of EastCentral Europe. We can hardly speak about division between political 'left' and 'right' and of the existence of ideological orientations that are typical of Western political life. The main role has been played by parties that were founded to serve the interests of the Kremlin executive elite. Currently, there are only four parties represented in the national legislative body, the Duma. The party that holds absolute majority of parliamentary seats, United Russia, ${ }^{6}$ consistently supports the policies of the current presidential administration (President Putin is also its former chairman). ${ }^{7}$ Others are Marxist-Leninist Communist Party of the Russian Federation, the ultra-nationalist Liberal Democratic Party of Russia and the neosocialist Just Russia. Some scholars speak about the 'cartelisation' of established parliamentary parties, i.e. their collusion in order to draw resources from the state and to set barriers to the entry of political 'outsiders' (Hutcheson 2012). This hinders competition and leads to closure of political space.

Russia's transition is characterised by a high level of elite reproduction, as shown by different studies on elite profile in former socialist countries (Szelenyi and Szelenyi 1995). ${ }^{8}$ Although some authors maintain that the new Russian political elite is of relatively recent date, since most of its members did not belong to ruling Soviet structures (see, for example, Lane and Ross, 1998), evidence shows that most of the elite circulation in Russia since 1989 has taken the form of promotion of individuals from the elite periphery to central positions so 'elite circulation has not resulted in the emergence of new social groups in positions of power but rather the retention of command positions on the part of old privileged groups' (Hanley, Yershova, and Anderson 1995, 667). High reproduction was due to the slow pace of social changes in other former socialist countries. Furthermore, there was no strong counter-elite that could have pushed out the Communist Party personnel. The barriers to the development of civil society within the Soviet system and the conditions causing weakness in social organisations in post-communist

6 united Russia was founded in December 2001 through a merger of the Unity and Fatherland-All Russia, two pro-Kremlinoriented political parties.

7 It is not an easy task to determine the ideological profile of the ruling Russian elite, led by President Putin and represented in the Duma by United Russia, in terms of placement in the left/right axis. It is combination of leftist and rightist sentiments, for example, nostalgia for former regime on the one hand, and nationalism and intolerance toward social minorities (like homosexuals) on the other.

8 The largest international comparative study on national elites, which was a part of the research project Social Stratification in Eastern Europe, was carried out by Ivan Szelenyi and his colleagues in the 1990s. By mid-1994, surveys were completed in six countries: Bulgaria, the Czech Republic, Slovakia, Hungary, Poland and Russia. During 1993-1994, they conducted interviews with approximately 40,000 respondents. In each country, they interviewed 2000 elite members: 1000 of them were in nomenklatura positions in 1988, 600 were members of the 1993 economic elite, and 400 were members of the 1993 political or cultural elite. In addition, a comparative sample of 5000 randomly selected members of the entire population was taken in each country. By the end of 1993, data were available in three countries: Hungary, Poland and Russia. 
Russia made it easier for members of the communist-era elite to subvert more essential and fundamental reforms (Evans 2011, 46).

The elite configuration in Russia thus does not represent fertile ground for successful democratization (Gel'man 2003). Under President Putin, Russia's political regime transformed from what had been sometimes referred to as a 'managed democracy', i.e. a political regime that restrained the scope of citizens' political choice by a variety of manipulative means, to a kind of 'electoral authoritarianism' (Golosov 2011) or 'populist autocracy (Fish 2018). ${ }^{9}$ Lynch speaks about neopatrimonial models which 'rest upon the tight nexus of wealth and political power' (Lynch 2005, 130). In post-communist Russia, 'a group from the ruling circles, consisting of Vladimir Putin and his closest supporters, has concentrated almost unchecked power in its hands, and has continued parliamentary and presidential elections, but has mastered techniques that make it possible for the ruling faction to manipulate the mass media, political parties, and public opinion so thoroughly that the outcome of a national election is always a foregone conclusion' (Evans 2011, 43).

\section{Slovenia}

The Slovenian political space is characterised by a division into two political blocs. The first is the so-called 'left-liberal' and the second the so-called 'right' bloc, with neither being fully internally homogenous (Adam and Tomšič 2002; Tomšič 2016; 2017). They are most clearly divided by their institutional origins. The two parties that for the most of transition period played the main role in first camp—the Liberal Democracy of Slovenia (LDS) and the Social Democrats (SD) (until 2005 called the United List of Social Democrats) have their organisational roots in the old (communist) regime; the latter is the successor to the former ruling Communist Party. ${ }^{10}$ The other bloc consists of three main parties: the Slovenian Democratic Party (SDS), which is the dominant party here, the Slovenian People's Party (SLS) and New Slovenia (NSi), which were established during the democratisation process (all three are members of the European People's Party).

The distinction between the 'old' and 'new' parties, as they are often labelled in public discourse, largely covers the left/right cleavage ('left' as the 'old' and 'right' as the 'new' parties). ${ }^{11} \mathrm{At}$

9 The Freedom in the World report (issued by Freedom House) placed Russia in the group of 'not free' countries since 2013.

10 It should be mentioned that the LDS acquired some special features. In 1994, a small but very significant group of members of two parties from the new political elite (members of the Demos coalition that governed from 1990 to 1992) joined the Liberal Democracy of Slovenia. 11 The labelling of both political blocs as 'the left' (first camp) and 'the right' (second camp), which is usual in public discourse, has been a paradox for a long time (and to some extent it has blurred the picture first, the cleavage mostly referred to the positions of the two camps in the past, meaning both the period between the two world wars and the communist period as well as to some other positions of a symbolic and ideological nature like the role of religion and the Catholic Church in society. (In this regard, the 'left' takes a quite lenient attitude to the communist period, while it is sceptical and does not reject the public engagement of the Church, while the 'right' is strongly critical of communism yet relatively supportive of the Church).

After the 2004 parliamentary elections, it appeared that political polarisation would ease, with the issue of socio-economic regulation gaining in importance. The campaign before these elections was evidently less burdened by the 'old' ideological issues. Lying at the forefront were issues related to the socio-economic regulation of society like liberalisation of the economy, tax reform and state welfare reform. When the rightleaning government launched the above-mentioned socioeconomic reforms, it encountered considerable reluctance from the opposition, which warned against an increase in social inequality and the impoverishment of a considerable share of the population, meaning it was demonstrating its 'leftist nature' in terms of its social orientation and scepticism regarding 'unleashed' capitalism. However, in the last few years, the animosity and conflict between the political camps has regained considerable strength. ${ }^{12}$

For most of the post-communist period, the Slovenian political space was dominated by a 'left-liberal' bloc in whom the LDS played a central part. ${ }^{13}$ The political domination of the "leftliberal' bloc was strongly related to the configuration of the general elite in post-communist Slovenia that is characterised by a fairly high level of reproduction in all elite sectors. ${ }^{14}$ The

of the Slovenian political space), since members of the business elite belong to proponents of 'the left', mostly the LDS, while many of those who considered themselves de-privileged (which is often described in terms of injustices suffered under the communist regime) have supported 'the right'.

12 The best example of such ideological activities is the decision of municipal authorities in the Slovenian capital, Ljubljana, to name a future street after the former Yugoslav communist leader Josip Broz Tito, a move that met with strong resistance from the centre-right opposition and a considerable share of the public, accusing the mayor and his followers of trying to rehabilitate the communist regime.

13 From the first parliamentary elections in 1990 onwards, there were nine 'political turns' (including the establishment of the first non-communist government in 1990, and the current one), in other words, changes of the political options in power (and five different heads of government, including the current one). However, in this (31year) period governments not dominated by 'left-liberal' parties were in place for just nine years. Although all LDS-led governments were composed of parties from different camps, this party dominated them and the 'spring parties' only played a marginal role in these coalitions. 14 The rate of reproduction amounts on average to $77 \%$, with the highest individual level being seen in the business sector (84\%) and the lowest in politics $(66 \%)$, while in culture it reaches $78 \%$ (Kramberger 1998; Iglič and Rus 2000). 
consequence was that the vast majority of the elite gravitated (regarding its voting preferences) towards the political part of the retention elite, represented by the LDS and SD. This faction of the political elite had much better connections with various strategic groups within society, above all the management, business and academic spheres, social sciences circles, and the media. Its advantage thus lay in its intellectual and cadre potential as well as its financial resources, which led to its disproportionate influence and informal power within society. ${ }^{15}$ This informal power contributed to the dominance of 'the left' more than their legitimate power, i.e. support among the population, since both blocs were more or less in balance (Adam and Tomšič 2002; 2012).

\section{Economic Transition and the Business Elite}

One of the crucial issues in the process of the systemic transformation of former communist societies was the establishment of conditions for the functioning of a market economy. So-called 'transition economies' (Stark and Bruzst 1998) thus had to introduce an institutional framework necessary for development of market activities and for privatisation of previously state-owned companies as well as for the change in cultural patterns in the business sphere.

\section{Russia}

In the socialist period, Russian economic system was characterised by a strict control of economic activities (Rutland 2006). At the beginning of the 1990s, Russian economic transformation started with shock therapy. Radical reforms were implemented in the Russian economic system, like economic liberalisation and privatisation. The aim of the implemented reforms was Russian integration in the international market economy. Elites were crucial players in implementing all these reforms, which covered liberalisation of prices and markets, disintegration of COMECON, demilitarisation of the economy, reduction of inflation, privatization, etc. (Åslund 1995, 140; Fotopoulos 2008).

The beginning of transition with the above-mentioned set of reforms was crucial for the emergence of the Russian business elite as we know them today, with privatisation, which began in 1992 as the key factor of their rise and power. Implementation of the shock therapy generated high levels of corruption during the first presidency of Yeltsin when state structures worked in accordance with the interests of local oligarchs, ${ }^{16}$ a relatively small group of individuals, which shared common interests and economic resources (Olson

15 This is, for example, very evident in the field of media. Namely, the media mainstream strongly favours leftist ideas and is aligned with the leftist political camp. See Makarovič et al. 2008; Tomšič et al. 2020.

16 The term oligarch means a great businessman who controls a sufficient number of resources to influence public policy (Guriev and Rachinsky 2004, 3).
1971). The Russian business elite was recruited from the ranks of elite of the Soviet nomenclature ${ }^{17}$ in the early stages of liberalisation (see Kryshtanovskaya and White 1996), meaning that the Soviet era elite adjusted to the changing political and economic system (Lazarev 2001, 3).

The economic system that developed in Russia in the 1990s was defined as 'oligarchic capitalism'18 (Menshikov 2005; Rutland 2006), with a high concentration of monopolies in key branches of industry, an underdeveloped banking system, and a shrinking social security infrastructure. Such a system tends towards high profit margins, it causes technological gap in the country, income inequality and mass poverty on the one hand, and the existence of a prosperous and affluent elite on the other. It reduces the scope of the domestic market and depends on the export of mineral resources at extremely high prices. Thus, production and high-tech production is neglected and the overall economic growth is unbalanced.

The Russian economic system can be also defined as 'crony capitalism' (Frye and Shleifer 1997; Johnson, Kaufmann, and Schleifer 1997; Åslund, 2019) with strong statistpatrimonial elements (Vasilieva-Dienes, 2018; 2019). This type of capitalism is typical for societies where economic success depends on political connections. The practical implications of such capitalism can be observed in favouring particular politically 'embedded' companies in giving licences and concessions and in uncontrolled tax evasion. The new Russian elite formed the so-called 'capitalism from above,' which occurred with managers gaining their privileged position by buying a majority share of factories and companies. This method of voucher privatisation enabled managers a dispersion of property, while bureaucrats (policy insiders) created investment funds to buy a number of vouchers, through connections and supervision of financial institutions (King 2002, 7-8).

With Vladimir Putin, as a successor to Yeltsin in 2000, a further transformation of the economic system began and particularly refers to the changing relationship between the political and business elites. Putin started to contest and restrict the power of already strongly entrenched oligarchs and pushed them into the shadows (Steiner 2001), establishing a state-led model of economy (Lane 2008).

The role of oligarchs has been disputed by many authors.

17 The Soviet elite consisted of individuals who were operating in the shadow of economy and from members from so-called intelligentsia, who advocated for a transition in the capitalist system (see Kotz and Weir 1997). New Russian bourgeoisie was recruited mostly from higher positions of former industrial nomenclature of the Communist Party of Soviet Union, state apparatus (directors of departments, the official young personnel, etc.), ministries of trade, and industrial associations (Steiner 2001).

18 Also known as: 'nomenclature capitalism' or 'criminalised capitalism' (see Hanson 1997; Menshikov 1999; 2005). 
While some perceive oligarchs as agents of institutional reforms and restructuring of Russian economy (see Boone and Rodionov 2002; Asslund 2004); others see them as 'parasites' who obtained their money from the funds of Russian companies send abroad, weakening the Russian economy and democratic institutions and causing large social inequality (see Stiglitz 2002; Goldman 2004).

The pace of economic reforms in Russia was uneven, resulting in a hybrid institutional setting. Although substantial progress was made in the last decade in some key areas (privatisation, change in employment policy, tax and pension system) (Simon 2004), the future of market reforms remains uncertain. In this period, Russia has been experiencing considerable economic growth which, however, strongly depends on its natural resources. The Russian economic system is still characterised by the 'extractive' conduct of the business elite who behave more as 'rent-seekers' than as agents of innovation and development (Kotz 2001). The business sphere remains highly politicised, since the business fortunes strongly depend on the political connections of their protagonists.

\section{Slovenia}

The collapse of the politico-economic system of so-called socialist 'self-management' in 1990 spurred changes where new socio-economic arrangements were established (Tomšič 2002, 143). Economic transformation was marked by the gradualist approach embraced by policy-makers at the beginning of the process of transformation of Slovenian society (Rojec et al. 2004). This gradualism was characterised by slow cautious reforms, especially in the economic field, reflected in staggering privatisation, maintenance of the high level of state interventionism, a low share of foreign direct investments, and the persistence of a large public sector. It was a result of the endogenous nature of the Slovenian transition, since it preserved the important role of the old business-managerial elite, which even in the new circumstances managed, with the strong assistance of the state, to retain a considerable part of its positions and oppose the further liberalisation of the economy that could harm the status quo. This approach was sustained by an ideology of 'national interest', which advocates domestic ownership of companies (at least those in strategically important branches); it was claimed that it brought more beneficial societal outcomes, since local owners are more attached to the community and are thus more socially responsible than foreigners, who care only for profits (Adam and Tomšič 2012, 63). This ideology was used by the hand of 'old' elite for preserving its positions through elimination of potential competitors from abroad. And it was maintained by the state through institutional mechanisms unfavourable to foreign investments.
In such circumstances, it was management that maintained a key role in managing business, leading to a setting some analysts have named 'managerial capitalism' (Szelenyi 1996; Eyal, Szelenyi, and Townsley 2000). This is a specific situation where the managerial class, in the absence of an ownership structure or in the presence of a weak one, controls the economy, thereby becoming a major, leading group in society.

Gradualism was strongly related to a high level of elite reproduction in the business sphere. Newcomers (circulation) has not weakened the old elite, but in the case of the new elite, we can speak about the 'retention elite', which is able to take advantages of its positions, which were mostly inherited from the old elite and regime (see Adam and Tomšič 2002). Among the Slovenian business elite, a high level of accommodation could be detached from the old elite which 'adjusted' its network (ties) with more important contact persons (Iglič and Rus 2000).

The Slovenian economy remains highly 'statised', meaning the role of the state and its control over the business sphere remain strong even after the country became an EU member (Tomšič and Prijon 2012). The share of state ownership of companies is the highest among countries in the region. Although at the beginning of the transition process gradualism brought certain advantages, since it tamed social disturbances and reduced the social cost of restructuring the business sector, it eventually started to produce negative effects, especially the reduced competitive potential of the national economy (as shown by results from different surveys like The World Competitiveness Yearbook) (Tomšič 2006; 2017). And these trends are evolving in an unpromising way. ${ }^{19}$ The global crisis has exposed all the deficiencies of the Slovenian economy and society in general, which is relatively heavily burdened by clientist networks, politicisation and monopolies that are not only present in the business sphere, but even more evidently in other spheres of society like education and health care. ${ }^{20}$

19 However, the situation improved in the last decade. In the World Competitiveness Yearbook 2010 prepared by the Institute for Management Development from Lausanne, on the competitiveness ladder, Slovenia was placed fifty-second in 2010 (among 58 countries and territories), while in 2020, it climbed to thirty-fifth place (among 64 countries and territories).

20 For example, in higher education only $3 \%$ of students are enrolled in non-state academic institutions, providing clear evidence of a monopoly over universities and the education system in general at the expense of diversity in terms of programmes and approaches in this strategically very important sphere. Further, institutions not integrated into the existing universities face different obstacles (for example, state co-financing of tuition fees for doctoral studies is limited solely to the universities, meaning the exclusion of doctoral students enrolled in independent schools). 


\section{Elites, Institutions and Development}

Russia and Slovenia established institutional settings that, in formal terms, considerably differ in some key aspects. In the political realm, Russia introduced a (semi)presidential system that concentrates power in the hand of president as the head of executive branch of government, while Slovenia adopted a parliamentary system, based on proportional representation that leads, at least in principle, to more dispersed power relations. In economic realms, differences with regard to the structure of business sectors derive from the 'nature' (extent, resources) of both economies: on one hand, Russia has a big economy with rich natural resources, on the other hand, Slovenia has a small and export-oriented economy with very limited resources. The economic reforms also took place in somehow dissimilar way: endurance of gradualism in Slovenia and changing approaches (liberalisation, etatisation) in Russia.

However, both countries share some important similarities with regard to the mode of recruitment of individuals to top positions in the key societal areas. Elite formation and performance is based on the principle of reproduction, i.e. the persistence of people with roots in former regime structures at top positions. Elite reproduction is considerably higher than in other comparable Central European countries (the Czech Republic, Hungary and Poland), where the change in the regime resulted in fundamental changes to the elite positions and thus the circulation of elites was higher (for Russia see White and Kryshtanovskaya 1998; Steiner 2001; for Slovenia see Kramberger 1998; Iglič and Rus 2000; Tomšič 2006; 2017).

Despite differences in the institutional character of the political system, there are similarities in terms of power-relations. In both cases, we witness an imbalance of power between different political groups: in Slovenia, it is one of the two politico-ideological camps that plays a dominant role, while in Russia, domination is exercised by a segment of the central state apparatus, gathered around President Putin.

A resemblance can also be observed in terms of the emergence of the business elite and their mode of action. It should be stressed that there are some evident differences between Russian oligarchs and the Slovenian business elite, especially regarding wealth and consequently lifestyle (amount of money, real estate, material goods, etc.). Nevertheless, they both maintain their positions through strong links with the state/ government, since their privileges strongly depend on political support. We can speak about a high level of politicisation of the economy, with a 'fusion' of the political and business elite. Consolidation of the powerful economic elite, who are strategically linked with the political elite, is present in many post-communist countries. The alliance between the political and economic elite operates on the principle of 'rent-seeker and rent-giver'. Rent-seekers gain additional profits by becoming the exclusive monopoly of the politically supported; on the other hand, rent-givers become the first to maintain and increase their political power (Hedlund 1999). Instead of promoting economic development and overall welfare, the Russian and Slovenian elite, both political and economic, instrumentalised power for a rapid increase in wealth, power, and their legitimacy (see Prijon 2012). Economies in both countries are not fully consistent with Western capitalism. The Russian economy does not develop evenly; the fiscal policy is not working properly, since the state prefers shortterm investments, which discourages the development of the economic sphere. There are no long-term investments; competition is mainly focused on the local level and exports are limited. A similar situation can be observed in the Slovenian economy, where the business culture of economic agents is often still based on properties of the former centrally planned management. Both countries are characterised by monopolies and a high level of economic closure. ${ }^{21}$

To be sure, there is a difference between the two countries with regard to the level of political, social, and economic monopolisation. While in Russia, power is strongly concentrated in the hand of President Putin, supported by a hegemonic party that has an absolute majority in the parliament, the change of government is practically unimaginable; in Slovenia, one can witness at least some circulation in power positions. While Russia's business sphere is strongly politically dependent and dominated by ruling elites, a certain part of the Slovenian business sphere (particularly foreign-owned as well as small and medium companies) is without political ties. However, Slovenia is still characterised by strong mechanisms of the 'deep state' (Pezdir 2021), which causes harm to the functioning of the rule of law (Avbelj and Lentar-Černič 2020) and has a detrimental effect on the developmental potential of society.

\section{Conclusion}

As mentioned in the introduction, Russia and Slovenia, at least at first glance, do not share many similarities, except for both being Slavic nations. Most of the studies and surveys on performance of former communist countries different aspects of post-communist transformation (democratisation, economic liberalisation, rule of law, etc.) place them on opposite polesSlovenia as one of the most successful transition countries and Russia in the group of problematic ones (especially regarding

21 In the Economic Freedom of the World 2021 annual report, issued by the Economic Freedom Network, Slovenia was regarding their economic freedom (measured by Economic Freedom Index) placed in the middle of the ranking table, i.e. fifty-seventh, while Russia was in the second half, i.e. in 100th place (among 165 countries). 
political modernisation). The institutional environment differs considerably as well. Slovenia is an integral part of the institutional setting of the EU, meaning that its political elite, regardless of its ideological orientation, cannot ignore the international institutional framework into which the country is integrated. On the other hand, Russia is an important world power that is in the position to determine its course of development in much more independent fashion.

However, one can hardly neglect some important commonalities as well, deriving from similar type and dynamics in an individual's recruitment to power positions. The composition of national elite, its cultural profile, and relations between different elite segments determined the course of institutional transformation.

Throughout their histories, both Russian and Slovenian society experienced institutional settings, based on 'extractive' principles, as defined by Acemoglu and Robinson (2012), characterised by exclusion, monopolies, and privileges for certain social groups. There were not many experiences with elements that would support 'inclusiveness'. After 1990, formal introduction of parliamentary democracy and a market economy brought the possibility of the development of an 'inclusive' system. However, the type of transformation, deriving from high level of elite reproduction and resulting in high 'retention' of certain principles from the former system, inhibited this process. It led to the establishment of a 'rentseeking' system that enables mutually entangled groups to maintain their privileged positions.

Elite reproduction and the extractive nature of the institutional setting hinder socio-economic development, regardless of the fact that Russia experienced economic growth in the last few years and that the Slovenian model had, at least in the initial phase of transition, evident advantages in terms on maintenance of social stability (Adam, Kristan, and Tomšič 2009). Implementation of structural reforms is necessary in order to overcome the crisis. This refers to the reform measures that would lead to dismantling of monopolies in different realms of society that are the major obstacle to modernisation and systemic competitiveness.

\section{References}

Acemoglu, Darren, and James Robinson. 2012. Why Nations Fail: The Origins of Power, Prosperity and Poverty. London: Profile Books.

Adam, Frane. 1989. "Deformirana modernizacija - (realni) socializem med tranzicijo in modernostjo." Družboslovne razprave 6(7): 19-30.

Adam, Frane. 1994. "After Four Years of Democracy: Fragility and Stability." Družboslovne razprave 15(1): 35-90.
Adam, Frane, and Matevž Tomšič. 2002. "Elite (Re)configuration and Politico-economic Performance of Post-socialist Countries." Europe-Asia Studies 54(3): 365-83.

Adam, Frane, and Matevž Tomšič. 2012. "The Dynamics of Elites and the Type of Capitalism: Slovenian Exceptionalism?" Historical Social Research 37(2): 53-70.

Adam, Frane, Matevž Tomšič, and Primož Kristan. 2008. "Political Elite, Civil Society, and Type of Capitalism: Estonia and Slovenia." East European Quarterly 42(1): 43-67.

Adam, Frane, Primož Kristan, and Matevž Tomšič. 2009. "Varieties of Capitalism in Eastern Europe (with a Special Emphasis on Estonia and Slovenia)." Communist and Post-communist Studies 42(1): 65-81.

Andorka, Rudolf. 1993. "Regime Transitions in Hungary in the 20th Century: The Role of National Counter-Elites." Governance 8(3): 358-71.

Arnason, Johann. 2000. "Communism and Modernity." Daedalus 129(1): 61-90.

Åslund, Anders. 1995. How Russia Became a Market Economy. Washington, DC: Brookings Institution.

Åslund, Anders. 2019. Russia's Crony Capitalism. New Haven, CT:: Yale University Press.

Avbelj, Matej, and Jernej Letnar Černič. 2020. The Impact of European Institutions on the Rule of Law and Democracy. Slovenia and Beyond. London: Hart.

Boone, Peter, and Denis Rodionov. 2002. "Rent Seeking in Russia and the CIS." https://www.researchgate.net/publication/247389256_ Rent_seeking_in_Russia_and_the_CIS.

Bozoki, Andras. 1994. "Confrontation and Consensus: On the Forms of Political Integration." In Democratic Legitimacy in PostCommunist Societies, edited by Andras Bozoki, 66-82. Budapest: T-TWINS Publishers.

Chaisty, Paul. 2005. "Party Cohesion and Policy-Making in Russia." Party Politics 11(3): 299-318.

Economic Freedom in the World. 2021. Vancouver: Fraser Institute.

Eisenstadt, Shmuel. 1973. Tradition, Change and Modernity. New York: Wiley.

Eisenstadt, Shmuel. 1992. "The Breakdown of Communist Regimes and the Vicissitudes of Modernity." Daedalus 121(2): 21-41.

Evans, Alfred. 2011. "The Failure of Democratization in Russia: A Comparative Perspective." Journal of Eurasian Studies, 2: 40-51.

Eyal, Gil, Ivan Szelenyi, and Eleanor Townsley. 2000). Making Capitalism without Capitalists. Ruling Class in Eastern Europe. London: Verso.

Field, G. Lowell, John Higley, and Michael G. Burton. 1990. "A New Elite Framework for Political Sociology." Cahiers Vilfredo Pareto 28(88): 149-81.

Fish, Steven M. 2018. "What Has Russia Become?" Comparative Politics 50(3): 327-46.

Fotopolous, Takis. 2008. "Transnational Elite and Russia: A New Bipolar World?" The International Journal of Inclusive Democracy 4(4): 1-9. 
Frye, Timothy, and Andrei Shleifer. 1997. "The Invisible Hand and the Grabbing Hand." American Economic Association, 87(2): 354-58.

Gel'man, Vladimir. 2003. "Russia's Elites in Search for Consensus." In Elites and Democratic Development in Russia, edited by Anton Steen and Vladimir Gel'man, 29-50. London: Routledge.

Goldman, Marshall. 2004. "The Rule of Outlaws is Over." Transition Newsletter, 14/15: 23-25.

Golosov, Grigorii. 2003. 'The Vicious Circle of Party Underdevelopment in Russia: The Regional Connection." International Political Science Review 24(4): 427-44.

Golosov, Grigorii. 2006. "The Structure of Party Alternatives and Voting Choice in Russia." Party Politics, 12(6): 707-25.

Guriev, Sergei, and Andrei Rachnisky. 2004. "Oligarchs: The Past or the Future of Russian Capitalism?" http://pdc.ceu.hu/archive/00001893/01/OwnershipConcentration_Aug2004.pdf.

Hanley, Eric, Natasha Yershova, and Richard Anderson. 1995. "Russia - Old Wine in a New Bottle? The Circulation and Reproduction of Russian Elites 1983-1993." Theory and Society 24: 639-68.

Hanson, Phillip. 1997. "What Sort of Capitalism is Developing in Russia?" Communist Economies and Economic Transformation 9(1): 27-42.

Haraszti, Miklos. 1977. Workers in a Workers' State. London: Penguin.

Hedlund. Stefan. 1999. Russia's 'Market' Economy. A Bad Case of Predatory Capitalism. London: UCL Press.

Huntington, Samuel. 1996. Clash of Civilizations and Remaking of World Order: New York: Simon \& Schuster.

Huntington, Samuel. 1993. The Third Wave: Democratization in the Late Twentieth Century. Norman: University of Oklahoma Press.

Hutcheson, Derek (2012): "Party Cartels beyond Western Europe: Evidence from Russia." Party Politics 19(6): 907-24.

Iglič, Hajdeja, and Andrej Rus. 2000. "From Elite Reproduction to Elite Adaptation: The Dynamics of Change in Personal Networks of Slovenian Elite." Družboslovne razprave, no. 32-33: 181-97.

Johnson, Simon, Daniel Kaufmann, and Andrei Schleifer. 1997. "The Unofficial Economy in Transition." Brookings Papers on Economic Activity 1997(2): 159-239.

Kaminski, Antoni, and Joanna Kurczewska. 1994. "Strategies of Post-Communist Transformation. Elites as Institution-Builders." In Social Change and Modernization: Lessons from Eastern Europe, edited by Bruno Grancelli, 131-52. Berlin: De Gruyter.

King, Lawrence. 2002. "Postcommunist Divergence: A Comparative Analysis of the Transition to Capitalism in Poland and Russia." Studies in Comparative International Development 37(3): 3-34.

Kleindienst, Patra, and Matevž Tomšič. 2017. "Human Dignity As the Foundation of Democratic Political Culture: Legal and Philosophical Perspective." Law, Culture and the Humanities. 1-20. https:// doi.org/10.1177/1743872117738229.

Konrad, György, and Ivan Szelenyi. 1979. Intellectuals on the Road to Class Power. New York: Harcourt Brace Jovanovich.
Kotz, David. 2001. "Is Russia Becoming Capitalist?" Science \& Society 65(2): 157-81.

Kotz, David, and Fred Weir. 1997. Revolution from Above: The Demise of the Soviet System. London: Routledge.

Kramberger, Anton. 1998. Positional Elites in Politics, Economy and Culture in Slovenia during 1988-95: Summary Statistics on Elite Segments. Ljubljana: CESTRA.

Kryshtanovskaya Olga, and Stphen White. 1996. "From Soviet Nomenklatura to Russian Elite." Europe-Asia Studies 48(5): 711-33.

Lane, David. 2008. "From Chaotic to State-led Capitalism." New Political Economy 13(2): 177-84.

Lane, David, and Cameron Ross. 1998. "The Russian Political Elites, 1991-95: Recruitment and Renewal." In Postcommunist Elites and Democracy in Eastern Europe, edited by John Higley, Jan Pakulski, and Wlodimierz Wesolowski, 34-66. London: Macmillan.

Lazarev, Valery. 2001. "Evolution and Transformation of the Soviet Elite." Hoover Institution. https://uh.edu/ pgregory/conf/SovElite.PDF.

Lynch, Allen. 2005. Reflections on Russian Political Development. Cambridge: Cambridge University Press.

Makarovič, Matej. 1996. "Neokorporativizem v sistemski perspektivi in njegova vloga v postsocialistični modernizaciji." Družboslovne razprave 12(2): 125-38.

Makarovič, Matej, Borut Rončević, Matevž Tomšič, Tamara Besednjak Valič, and Urša Lamut. 2008. Slovenski mediji v družbi in slovenska družba $v$ medijih medijev [Slovenian media in society and Slovenian society in media]. Nova Gorica: Fakulteta za uporabne družbene študije.

Menshikov, Stanislav. 1999. "Russian Capitalism Today." Monthly Review 51(3): 81-99.

Menshikov, Stanislav. 2005. "The Anatomy of Russian Capitalism." Challenge 48(2): 67-89. https://www.jstor.org/stable/40722305.

Offe, Klaus. 1993. "Capitalism by Democratic Design: Theory Facing the Triple Transition in East Central Europe." Social Research 58(4): 865-92.

Olson, Mancur. 1971. The Logic of Collective Action: Public Goods and the Theory of Groups. Cambridge, MA: Harvard University Press.

Pezdir, Rado. 2021. Vzporedni mehanizem globoke države [Parallel Mechanism of Deep State]. Ljubljana: Podjetniška analitika.

Prijon, Lea. 2012. "Power and Position of Slovenian Political and Economic Elite after Transition: Who Really Rules Slovenia?" Innovative Issues and Approaches in Social Science 5(2): 242-65.

Rizman, Rudi. 1989. "Problem modernosti in modernizacije v kontekstu teoretične sociologije [Problem of modernity and modernisation in context of theoretical sociology]." Družboslovne razprave 6(7): 7-18.

Rojec, Matija, Janez Šušteršič, Boštjan Vasle, Marijana Bendaš, and Slavica Jurančič. 2004. "The Rise and Decline of Gradualism in Slovenia." Post-Communist Economies 1(4): 459-82.

Rutland, Peter. 2006. "Oil and Politics in Russia." Paper presented at the annual convention of the American Political Science Association. Philadelphia, PA, September 2. 
Schmitter, Phillippe C. 1993. "The Consolidation of Democracy and Representation of Social Groups." American Behavioral Scientist 35(4-5): 422-46.

Simon, György. 2004. "Market Reforms in Russia - Problems and Prospects." Razprave i članci 55(2-3): 1-30.

Stark, David, and Laszlo Brusz. 1998. Postsocialist Pathways: Transforming Politics and Property in East Central Europe. Cambridge: Cambridge University Press.

Steiner, Helmut. 2001. "Privatisation and the Emergence of New Business Elites in Russia." WZB Discussion Paper, no. P 01-004. Wissenschaftszentrum Berlin für Sozialforschunghttp://hdl.handle. net/10419/50246.

Stiglitz, Joseph. 2002. Globalization and Its Discontents. New York: W. W. Norton.

Szelenyi, Ivan. 1996. "Vzpon menedžerizma: 'novi razred' po padcu komunizma [Rise of managerialism: 'new class' after the fall of communism]." Nova revija, 172/173: 1-13.

Szelenyi, Ivan, and Szonja Szelenyi. 1995. "Circulation or Reproduction of Elites during the Post-Communist Transformation of Eastern Europe." Theory and Society 24: 615-38.

Tomšič, Matevž. 2002. Politična stabilnost v novih demokracijah [Political stability in the new democracies]. Ljubljana: ZPS.

Tomšič, Matevž. 2006. "Kulturne značilnosti slovenskih elit v luči evropskih integracijskih procesov." Družboslovne razprave 22(51): 73-91.
Tomšič, Matevž. 2012. Elites in the New Democracies. Frankfurt am Main: Peter Lang.

Tomšič, Matevž. 2017. "Crisis and (Re)Structuring of Slovenia Political Space." In Slovenia. Social, Economic and Environmental Issues, edited by Frane Adam, 37-54. New York: Nova Science Publishers.

Tomšič, Matevž, Borut Rončević, Nuša Erman, and Tamara Besednjak Valič. 2020. Raziskava medijske krajine: raziskovalno poročilo [Research on media landscape: research report]. Ljubljana: Fakulteta za medije. https://www.gov.si/assets/ministrstva/MK/ Novice/Raziskava-medijske-krajine.pdf.

Tomšič, Matevž, and Lea Prijon. 2012. "Slovenia." In Life in PostCommunist Eastern Europe after EU Membership: Happy Ever After?, edited by Donnacha, Ó Beachain, Vera Sheridan, and Sabina Stan. 95-114. London: Routledge.

Vasilieva_Dienes, Alexandra. 2018. "Trapped in Informality: The Big Role of Small Firms in Russia's Statist-patrimonial Capitalism." New Political Economy 23(3): 314-30.

Vasilieva_Dienes, Alexandra. 2019. "Informality Trap: A Foundation of Russia's Statist-Patrimonial Capitalism." Contemporary Politics 25(3): 334-52.

Wold Competitiveness Yearbook. 2020. Lausanne: Institute for Management Development.

Wold Competitiveness Yearbook. 2010. Lausanne: Institute for Management Development. 